\title{
Semmi sem ciki
}

"A fizikai törvények mind igazak, ha nem vesszük figyelembe a gravitációt és a súrlódást." (egy barátom apjától)

„Don Juan: Miért ne érdemelnéd te is ugyanazt, amit a többi orvos? Nekik sincs több közük a beteg gyógyulásához, mint neked. Az egész tudományuk tiszta szélhámosság. Ha a beteg véletlenül meggyógyul, maguknak tulajdonítják a dicsőséget, miért ne húzhatnál te is ugyanígy hasznot abból, ha a beteg jobban van. Hadd higgye, hogy csakis a te gyógymódodnak köszönhet mindent, ami a véletlen kegyéből, vagy a természet erejéből történt.

Sganarelle: De uram! Ön az orvostudományban sem hisz?

Don Juan: Az emberiség egyik legnagyobb eltévelyedése."

(Moliére: Don Juan)

Még az is lehetne a kérdés, lehet-e erről a könyvről recenziót írni. Megéri-e egyáltalán? Találni lehet-e benne olyan szálakat, amelyekre felfüzhető a szöveg gondolatmenete? És persze ezek még csak az írás problémái...(a könyvvel kapcsolatos problémák). De nem kell-e mindig számot vetni azzal is, hogy milyen közösség az, amelyiknek meg kell felelni, milyen olvasótábor igényeit lehet kielégíteni vele, azaz milyen feltételek mellett, milyen elöre bevett formulákat, fordulatokat kell alkalmazni ahhoz, hogy megjelenhessen? És kinek áll hatalmában megítélni ezt? 
Feyerabend: A módszer ellen ${ }^{1}$ címü, magyarul teljes fordításban elöször megjelent könyve maga a számonkérő káosz. A számonkérés tétje mindig az a kérdés, kinek van joga megítélni egy tudományon belül, melyek az üdvözítő elméletek, és melyek azok, amelyek kiesnek a szórásból bizonyos okoknál fogva. Feyerabend szövege a tudományos döntéshozatalok metódusába próbál betekintést nyújtani, állandóan hangsúlyozva, hogy végtelen naivitás lenne részünkröl, ha azt hinnénk, hogy a tudományos elméletek kiválasztásakor csakis a valószínüség, a racionalitás vagy pragmatikusságuk játssza a fő szerepet. Sőt, (szerinte ez a „normális”) tudományon kívüli dolgok határozzák meg egy-egy elmélet történetét vagy éppen elvetélését. Ekkor azonban át kell fogalmazni a kérdést: kinek áll hatalmában megítélni az elméleteket?

De nem csupán az elméletek külső megítélésének a szükségképpeni velejárója a tudománykívüliség, hanem minden racionális érvmenet legbelsőbb mozgatórugója is. Feyerabend azok ellen a tudományok ellen beszél, amelyek fennhangon állítják magukról, hogy az igazság letéteményesei, vagy hogy a tiszta racionalitáson kívül semmilyen módszerre nincs szükségük a megismeréshez, sőt, nem is befolyásolják immanens müködésüket kulturális beidegződések.

Ezeket a naiv vagy éppen a hatalmi pozíciók miatt elkendőzött előfeltevéseket cáfolja meg rendre érveivel, amihez fizikai, termodinamikai megfontolásokat éppúgy figyelembe vesz, mint a boszorkányperek eljárásait, vagy Parmenidész filozófiáját ${ }^{2}$. Egységes elmélet nem igazán bogarászható ki ebből a gondolat-aggregátumból, ami összefogja mégis, az egyfajta tudatos vagy felügyelt káosz-felfogás.

Ennek letéteményese a már szinte aforizmává vált „,anything goes”, ebben a kiadásban „,bármi megteszi” - ként szerepel. A fordító megemlíti, hogy talán ez a legjobb fordítás, amit eddig hallott, bár szerintem a semmi sem ciki (igaz nem annyira közismert) formula jobban beleillene a szövegkörnyezetbe figyelembe véve Feyerabend tudatosan retorizált regiszterkeverő beszédmódját. ${ }^{3}$

Feyerabend káoszának legnagyobb és bevallottan legfontosabb fegyvere a nyelv. Mondatai mindig reflektálnak az általuk hordozott folyamatokra, tekintettel vannak rá, éppen mi történik bennük; úgy is mondhatnám, a

\footnotetext{
${ }^{1}$ Paul Feverabend: A módszer ellen, Atlantisz, 2002.

${ }^{2}$ Szerinte nála találhatjuk az első nyomokat a tudomány racionális elhülyülésére.

${ }^{3}$ Kimondom, na, jobban tetszene neki. Még megboldogult irodalomelméletes koromban halottam ezt a „schlagwort”-ot a letiltó értelmezések ellen vérben forgó szemekkel tiltakozó irodalmárok szitkozódó szájából.
} 
szöveg azt teszi, amit mond. Ellehetetlenít, amennyire csak lehet, látszólagos rendezettsége abszolút rendezetlenséget takar, stílusa néhol a kocsmai pocskondiázásra, máshol képletekkel, ábrákkal tủzdelt iskolai tankönyvekre vagy éppen szigorúan felépített tudományos értekezésre emlékeztet. Nem tart ki egyetlen álláspont mellett sem, csupán a pluralizmust üdvözíti. Érvei hol tudományos tényekre hivatkoznak, hol csupán pillanatnyi hangulatok lecsapódásaiként hatnak: állandó vibrálás az érzelmi-hangulati elemekre való hivatkozás, a teljes inkonzisztencia és a hüvös racionalitás között, persze gondosan bizonygatva ez utóbbi lehetetlenségét.

Ezek után nem meglepö, hogy számon kéri a tudósokon nyelvezetük kegyetlen szárazságát, akik sivatagossá próbálják tenni alapvetően tropikus nyelveinket, és nem veszik figyelembe, hogy ezzel „megsértenek egy társadalmi kritériumot, tudniillik, hogy az emberekhez mint emberekhez kell szólniuk, nem pedig mintha azok kövek volnának."4 Valamiféle humanitás nevében beszél a - nevezzük így - bevallás moráljáról. Ha úgyis antropomorfizálnak a tudományok, miért nem vallják be magukról? Ha téziseik ad hoc elméleteken, érzelmi-hangulati alapú választásokon múlnak, miért nem képesek ezt is expliciten megfogalmazni? Miért kell a tudósoknak elrejteni „emberiességüket”, asszociációikat, vágyaikat, humorukat, mindennapjaikat befolyásoló emócióikat egy leginkább már csak mitikus szobatudós-kép kedvéért, aki csak és kizárólag a tudománynak él? Ha végre megtennék és bevallanák önnön meghatározottságukat is a racionalizmus tisztaságának hazugságában dorbézolók, emberibb nyelven tudnának megszólalni. Márpedig Feyerabend szerint ez a nem elhanyagolhatóan kis lépés csak előnyére változtatna a tudományoknak. Jelesül még haladásukat is elősegítené: „Ha világossá válik, hogy szoros empirikus megfelelés nem erény ${ }^{5}, \mathrm{~s}$ hogy a változás korszakaiban célszerü eltekintenünk tőle, akkor a stílus, a kifejezés eleganciája, a prezentálás egyszerüsége, a cselekmény és a narratíva feszültsége s a tartalom csábereje fontos jegyei lesznek tudásunknak. Élettel töltik meg a mondottakat, és segítenek megtörni a megfigyelési anyag ellenállását."

A tudományos nyelvezet megváltozásának persze sokkal messzebbre mutató következményei vannak. Feyerabend nem győzi hangsúlyozni nyelv és gondolkodás kölcsönös egymástól való függését. A tudományos leírások nem ritkán élnek a szavak adta asszociációs lehetőségekkel, azaz csupán

\footnotetext{
${ }^{4}$ P. Feyerabend: I. m. 265

${ }^{5}$ Lásd például a Galileiről szóló fejezetek

${ }^{6}$ I.m. 258
} 
képi, hangalaki, metaforikus hasonlóságok is közbejátszanak egy-egy „tényleges” folyamat megfigyelésének lejegyzése alkalmával, amelyeknek vajmi kevés közük van a szigorúan megfogalmazott alapelvekkel szabályozott empirikus módszerekhez. Ha tehát ez így van egyébként is, miért ne tehetnénk explicit formában ugyanezt? Miért ne emelhetnénk be az elméleteket megítélő szabályok közé, hogy például ne legyenek unalmasak? Nagyobb hangsúlyt fektethetnénk az emberi kreativitásra, az egyéniség hangsúlyozására.

Csakis cselekvő, hús-vér emberek lehetnek a pluralizmus képviselöi, nem névtelen elméletek, tehát egyáltalán nem arról van szó, hogy a bármi megteszi (semmi sem ciki) elvét megtehetnénk egy általánosan elfogadott viszonyítási alapnak, amihez aztán majd hozzámérhetjük a különböző elméleteket. Ezzel ugyanabba a csapdába esnénk, mint a racionalizmust mindenek felett hirdető, saját tanaikat az igazság kizárólagos letéteményesének gondoló „hataloméhes” tudósok. Nem lehet egyetlen tétel megfogalmazásával megreformálni a tudományt, „nem az általános szabályok egyik körét akarom egy másikra cserélni; az a célom, hogy meggyőzzem az Olvasót, minden metodológiának, a legmeggyözőbbnek is, megvannak a határai..."

Viszont azt sem gondolom, hogy ,...ez az anything goes, amit Feyerabend az újat teremtő tudományok szempontjából az egyedül lehetséges magatartásnak tekint, nála puszta leírása annak, ahogyan a tudomány müködik, nem pedig a kívánatos világviszonyulás." " Elóírás és leírás megkülönböztetése visszavezet arra a problémára, amit a fentiekben a bevallás moráljának neveztem. A tudomány, miközben megteremti a valóságait, és leírást ad róluk, szükségszerüen megfogalmaz imperatívuszokat a helyes világlátás, a megfelelő magatartásformákat stb. illetően, de úgy tesz, mintha ezek egyáltalán nem léteznének. Ha ez nem így lenne, Feyerabend nem kérhetné számon a tudományos elméletek megítélésében, hogy nem veszik figyelembe azok társadalmi, etikai következményeit ${ }^{9}$. Márpedig ez a bármi megteszi gondolatának egyik legfontosabb belátása. Preskripció és deskripció elválasztása éppannyira lenne önmagunk meghazudtolása, mint teszik ezt egy tudomány történetének és elméletének megkülönböztetésével.

\footnotetext{
${ }^{7}$ I.m. 530

${ }^{8}$ Vajda Mihály: Bármi megteszi? Élet és irodalom 2003. február 21.

${ }^{9}$ Ezért üdvözíti például az egyházat Galilei tanainak elvetésében, mert nem csak a Szentírásra való tekintettel tette ezt, de társadalmi veszélyeit is figyelembe vette.
} 
Hogyne lehetne a tudományok nélkül élni, csak valljuk be, hogy túl nagy szerepet kaptak mindennapjainkban, túl nagy a hatalmuk. Vallásunkat megválaszthatjuk, de az, hogy mit tanuljunk, törvényekbe van foglalva. Az iskolákban az objektívizmus és az igazság szószólóiként nyomnak el minden olyan próbálkozást, amelyben a gyerekek fejleszthetnék (vagy nem veszítenék el) kreativitásukat ${ }^{10}$. Feyerabend javaslata, hogy a tudományt el kell választani az államtól, vissza kell adni megítélésüket az emberek kezébe (szerinte akár szavazások függvénye is lehetne). Ráadásul nem szabad kizárni azt a lehetőséget sem, „..hogy a sokféleséget némelykor tudományon kívüli instanciáknak kell kikényszeríteniük (kiemelés tölem: S. R.), mert nekik van elegendö hatalmuk ahhoz, hogy a leghatalmasabb tudományos intézményeken is felülkerekedhessenek. Példaként említhető az egyház, az állam, a politikai pártok, a közelégedetlenség vagy a pénz..."11 Ezért némileg egyoldalúnak érzem Vajda recenziójának következtetését, hogy Feyerabend ,jámbor javaslata” csupán a tudomány elválasztása az államtól. És belátható, hogy ez sem mindig igaz. Az elérni kívánt cél, hogy megszabaduljunk az elméletek nyomásától és/vagy morális kényszerétől, mert „az objektív irányelvek hajkurászása ellentmond az egyéni felelősség eszméjének, amely állítólag lényegi összetevője egy $<<$ racionális $>>$ vagy tudományos kornak."12

Nem elméleteket, nem az államot, még csak nem is az Embert illeti meg a tudományok feletti hatalom, hanem az egyes hús-vér embereket; azaz azt az irányított káoszt, amely nem ismer el maga felett semmilyen instanciát. ${ }^{13}$ Szakértők és laikusok közti határvonalak örökre elmosódtak. Az emberek határozzák meg, hogy milyen kutatásokra kívánnak pénzt adni, mit tanítsanak az iskolákban, és ne néhány beavatott igazságától függjön. „Dollármilliárdok, magasan képzett asszisztensek és többéves kemény munka szükségleltetett ahhoz, hogy néhány világos beszédre képtelen és meglehetősen korlátolt kortársunk egy-két bukdácsoló lépést tegyen egy olyan helyen, ahová épeszü embernek sosem jutna eszébe ellátogatni - egy kiszáradt, forró kőrakáson, hol még levegő sincs."14

${ }^{10}$ És ez, meglátásom szerint nem csak a természettudományokkal van így. Még a középiskolai irodalom-oktatás is tobzódik a bevett értelmezésekben, amit a diáknak vissza kell böfögnie.

${ }^{11}$ P. Feyerabend: I. m. 498

${ }^{12}$ I. m. 557

${ }^{13}$ Egyébként Feyerabendnek ez a már szinte kamaszos utálkozása bármilyen autoritással szemben néha túllő a célján. Nem válhat mindenkiből anarchista!

${ }^{14}$ I. m. 528 Ebben a formában ez lehet, hogy túl erős, de sokat gondolkoztam már azon, hogy a teflonbevonatú edényeken és a mikrohullámú sütőn, valamint a 
És kinek van joga megítélni ezt a könyvet? Nekem, semmi sem ciki!

Challanger és a Columbia katasztrófáján kívül mi értelme van ennek az eszeveszett ürhajósdinak. 